\title{
An Assessment of Fresh Water Piscine Diversity in Selected Wetlands in Coimbatore District, Tamilnadu, India-A Preliminary Study
}

\section{B. Dhanalakshmi, P. Priyatharsini}

PG and Research Department of Zoology, Nirmala College for Women, Coimbatore, India Email: dr.dhanalakshmi02@gmail.com

Received 10 December 2015; accepted 25 December 2015; published 28 December 2015

Copyright (C) 2015 by authors and OALib.

This work is licensed under the Creative Commons Attribution International License (CC BY). http://creativecommons.org/licenses/by/4.0/

c) (i) Open Access

\section{Abstract}

In the present study, a survey was done to mainly focus on piscine diversity in the wetlands of Coimbatore District, because it is considered as a good indicator of balanced and healthy ecosystem. The present survey study has shown that selected sampling site (Perur, Muthanankulam and Kurichi) wetlands supported 40 species of fishes belonging to 4 orders 07 family and 21 species during the study. Among the species, Cyprinidae was the most dominant group representing 08 species, Siluridae with 03 species, Ophiocephalidae with 03 species, Bagridae 2 species, Anabantidae 1 species, Heteropneustidae 1 species, Clariidae 1 species and Cichlidae 1 species. It can be concluded that all the selected wetlands supported rich repository of indigenous fish population but still it needed proper management and sustainable steps to monitor and conserve fish wealth for utilization of consumers' health, fish industry producers and researchers and fishermen.

\section{Keywords}

Ichthyofaunal Diversity, Wetlands, Freshwater Fish

Subject Areas: Aquaculture, Fisheries \& Fish Science, Environmental Sciences

\section{Introduction}

Planet earth, an ecosphere is made up of five components within which the biosphere water is an essential component which highly depends on water quality and biological diversity. According to Ehrlich and Wilson [1] biological diversity means stabilization of ecosystem, protection of overall environmental quality for understanding intrinsic worth of all species including the entire living organism (plants and animals) with their genetic ma- 
terial on the earth. In most of the urban ecosystems, ecologically wetlands are unique major life-supporting component having rich nutrient status with immense production potential, high population of birds, mammals, reptiles, amphibians, fish, invertebrate species and fodder resources for human and its related allies.

India, one of the mega biodiversity countries in the world occupies ninth position in terms of freshwater mega biodiversity having 2500 species of fishes of which 930 live in freshwater and 1570 in marine. Globally nature as well as animal diversity are affected due to increase in unwise anthropogenic activities mainly aquatic ecosystem gets adversely affected due to release of wastes in it. The wetlands (ponds, lakes and river) are the lifeline of the people resides in nearby villages mostly for various domestic activities.

Noyyal River, a tributary of Kaveri River, was noted for its capricious nature as they supported different food chain, food webs, regulate hydrological cycle, recharging ground water, trapping of energy and shelter to large numbers of flora and fauna having great ecological and economical value. All the selected wetlands in the present study are Noyyal riverine in origin surrounded by 10 villages covering 8070 hectare area of wetland which includes 304 small wetlands $(<2.25$ hectare) to Natural wetland $(44.30 \%)$ and Man-made $(55.70 \%)$ of Coimbatore District geographic area providing water for cultivation in the nearby agricultural land but also maintain the ecosystem of the area through preservation of many species of aquatic plants, fishes, insects, birds, underwater animals and domestic as well as migratory birds.

From time immemorial millions of human are suffering from hunger and malnutrition for which fishes are provided in the form of rich palatable protenious source of meal to tide over a nutritional difficulties of man. It is one of the good and cheapest sources of protein food for economic as well as high class people, so it is essential to study the distribution and the availability of fish from freshwater reservoirs and tanks. The objective of the present study was to make a surveillance offish faunal diversity of wetlands and to present a documentary record of fish species in order to maintain sustainable development and stability of wetland ecosystem in Coimbatore District.

\section{Materials and Methods}

Study area: Coimbatore, the second largest city in the Indian state of Tamil Nadu is surrounded by the Western Ghats on all sides at $11^{\circ} 00^{\prime} 58^{\prime \prime} \mathrm{N} 76^{\circ} 58^{\prime} 16^{\prime \prime} \mathrm{E} 11.0161^{\circ} \mathrm{N} 76.971^{\circ} \mathrm{E}$. This lovely industrial city is situated on the banks of the Noyyal River which originates from the Vellingiri Hills and flows towards the East and joins the river Cauvery. The city sits amidst Noyyal's basin area and has an extensive tank system fed by Southwest monsoon but the Northeast monsoon rainwater. The eight major lakes/wetland areas of Coimbatore are-Perur, Muthanankulam, Kurichi, Ukkadam, Singanallur, Sulur, Selvachinthamani, and Kumaraswami lakes which are interconnected along the $173 \mathrm{~km}$ long river to rejuvenate ground water in this area which was known for scanty rainfall. These interconnected tanks, their canals and rivulets also formed an active flood buffer for the river. Over a period of time, these wetlands came to house a lot many species of birds, fish and other life forms in pristine glory.

Methodology: The survey work on Perur, Muthanankulam and Kurichi wetlands of Coimbatore district was spanned from November (2014) to January (2015). Common fishes were recorded in the landing site, and a sample collection was made for certain species for further laboratory confirmation.

Collection of Fish: Fish samples were collected every month using cast nets (dia. $3.7 \mathrm{~m}$ and $1.0 \mathrm{~m}$ ) for collecting fish in shallow areas, monofilamentaous gill nets (vertical height $1.0 \mathrm{~m}-1.5 \mathrm{~m}$; length $100 \mathrm{~m}-150 \mathrm{~m}$ ), drag nets (vertical height $2.0 \mathrm{~m}$ ) and a variety of traps during the study period from the fish landing centers with the help of skilled local fishermen. Sampling points were distributed throughout the site to cover its whole area.

Laboratory Procedures: Immediately photographs were taken prior to preservation since formalin decolorizes the fish colour on long preservation. Fish species which were not identified in the spot were brought to laboratory preserved in $10 \%$ formalin solution in separate specimen jar according to the size of specimen with proper spreading of their fins. Two changes of $10 \%$ formalin were adopted during the sampling time. Smaller fishes were directly placed in the formalin solution while, larger fishes were given an incision on the abdomen before they were fixed. Each container was labeled properly against the physical data sheet of sampling and brought to the laboratory for further taxonomic exercise.

Identification of Fish Species: All fish caught were identified to species level using standard taxonomic viz. Fishes of India, FAO identification sheets, ITIS (Integrated Taxonomic Information System) standard report (http://www.itis.gov), and other reference books using standard keys of Jayaram [2], Qureshi and Qureshi [3], 
Talwarand Jhingran [4], Day Francis [5] and Shrivastava [6]. Fish Basewebsite was also referred for various aspects of fishfauna (www.fishbase.org).

\section{Results and Discussion}

In the present study, the selected major wetlands were Perur, Muthanankulam and Kurichi belonging to Coimbatore district, Tamilnadu, India fed by Noyyal river were discussed below based on icthyofaunal diversity. Wetland I (Perur) is situated close to Sundakkamuthur village with a catchment area of $2.227 \mathrm{Sq}$. Km with water storagecapacityup to $51.94 \mathrm{MCft}$ and water level up to $4.51 \mathrm{~m}$ and lies in between Latitude-10 $58^{\prime} 06 \mathrm{\prime \prime} \mathrm{N}$ and Longitude-76 ${ }^{\circ} 55^{\prime} 41$ "E. This site is an important roosting site of Pelicans, Painted stork, Open-bill stork, Pond herons, Egrets, White-breasted waterhens, Purple Moorehens, Darters, Cormorants, Kingfishers, grebes, Spotbilled ducks and coots. Icthyofaunal diversity surveillance of this particular wetland recorded a total of 11 species of primary freshwater fishes belonging to 5 families and 4 orders. Number of species and their relative abundance is given in Table 1. In the assemblage structure, cyprinidae constituted the dominant group and the cyprinid Labeo rohita, Catla catla, Cirrhinus mrigala, Cyprinus carpio, and Cyprinus carpio carpio were recorded in this study site. The family Cyprinidae dominated with 5 species followed Cichlidae, Bagaridae and Heteropneustidae family each with 1 species, beside other family as Ophiocephalidae, (Figure 1).

The present result was in accordance to many researchers like Kharat et al. [7], Galib et al. [8], Nagabhushana and Hosetti [9], Chandrashekhar [10], Biswas and Panigrahi [11]. In their investigation on ichthyofaunal diversitythere was strong dominance of Cyprinidae family. Sakhare [12] reported 23 species belonging to 7 orders where Cyprinidae family was dominant with 11 species from Jawalgaon reservoir. Choube et al., [13] reported 45 species in Rajnandgaon town of CG, India where Cyprinadae was the largest dominant family contributing 20, species and Bagridae formed the sub dominant family.

\section{Table 1. List of ichthyofaunal diversity of selected wetlands.}

\begin{tabular}{|c|c|c|c|c|c|}
\hline S. No. & Order & Family & Species & Author & Status \\
\hline 1. & Cypriniformes & Cyprinidae & Catla catla & Hamilton, 1822 & +++++ \\
\hline 2. & & & Cirrihinus mrigala & Hamilton, 1822 & +++++ \\
\hline 3. & & & Cyprinus carpio & Linnaeus, 1758 & +++++ \\
\hline 4. & & & Labeo rohita & Hamilton, 1822 & +++++ \\
\hline 5. & & & Cyprinus carpio carpio & Hamilton,1822 & +++ \\
\hline 6. & & & Ctenopharyngdon idella & Valenciennes, 1844 & +++ \\
\hline 7. & & & Labeo fimbratus & Bloch & +++ \\
\hline 8. & & & Labeo calbasu & Hamilton, 1822 & +++ \\
\hline 9. & Ophiocephaliformes & Ophiocephalidae & Channa marulius & Hamilton, 1822 & ++ \\
\hline 10. & & & Channa punctatus & Bloch, 1793 & ++ \\
\hline 11. & & & Channa striatus & Bloch, 1794 & ++ \\
\hline 12. & Perciformes & Cichlidae & Oreochromis mossambicus & Peters & ++++ \\
\hline 13. & & Anabantidae & Anabas testudineus & Bloch, 1792 & +++ \\
\hline 14. & Siluriformes & Heteropneustidae & Heteropneuteus fossilis & Bloch, 1974 & +++ \\
\hline 15. & & Bagridae & Mystus vittatus & Bloch, 1794 & +++ \\
\hline 16. & & & Mystus seenghala & Skyes, 1839 & - \\
\hline 17. & & Clariidae & Clarias batrachus & Linnaeus, 1754 & ++ \\
\hline
\end{tabular}

*++++- Most abundant; +++- Abundant; ++- Less abundant; - Rare. 
Wetland-II (Muthanakulam wetland) is situated West of Coimbatore city within the Latitude $11^{\circ} 00.283^{\prime} \mathrm{N}$ and Longitude $76^{\circ} 55.237^{\prime} \mathrm{E}$ with catchment area of 26 Sq. Kmand water storagecapacity of $7.67 \mathrm{MCft}$. A good number of migratory birds like Pelicans, Painted stork, Open-bill stork, Pond herons, Egrets, White-breasted waterhens, Purple Moorehens, Darters, Cormorants, Kingfishers, grebes, Spot-billed ducks and coots roost in this wetland. During the present piscine inventory study at Muthanakulam wetland, 13 species of 7 different families and 4 orders were recorded. The members of the orders Cypriniformes were dominated by 6 species followed by order Ophiocephaliformes of members with 1 family with 2 species. Next to order Ophiocephaliformes order perciformes was more abundant with 2 family Cichlidae and Anabantidae followed by order Siluriformes with 2 families Bagridae and Heteropneustidae. Catla catla, Cirrihinus mrigala, Cyprinus carpio, Labeorohita Channa marulius Channa striatus, Oreochromis mossambicus fish species of Cyprinidae, Ophiocephalidae and Cichlidae were most abundant than the other fish species (Figure 2). Similar results were observed by Narsimha and Benarjee [14] and Nagma and Afzal Khan [15].

Wetland-III (Kurichi wetland) with catchment area of 4014 acres with water capacity of 60.00 M.cft and depth of 10.75 feet with Icthy of aunal diversity of15 fish species representing by 4 orders and 6 families was observed in the Kurichi wet land. Among the 4 order Cypriniformes was dominant with 7 species. Cyprinidae was dominant family in this assemblage composition in which fish species like, Catla catla, Cirrhinus mrigal, Labeorohita and Cyprinus carpio were found abundant. During the present investigation in the Kurichi wetland the order of dominance was as follows. Cypriniformes $>$ Perciformes $>$ Ophiocephaliformes $>$ Siluriformes. The lake had a mixed fish culture of different fish species of different families. Among the families the Cyprinidae was recorded maximum with 7 species while the Bagridae with 2 species and Claridae with 1 species were recorded (Figure 3). The third major population of fish species was Channa marulius, Channa striatus and Channa
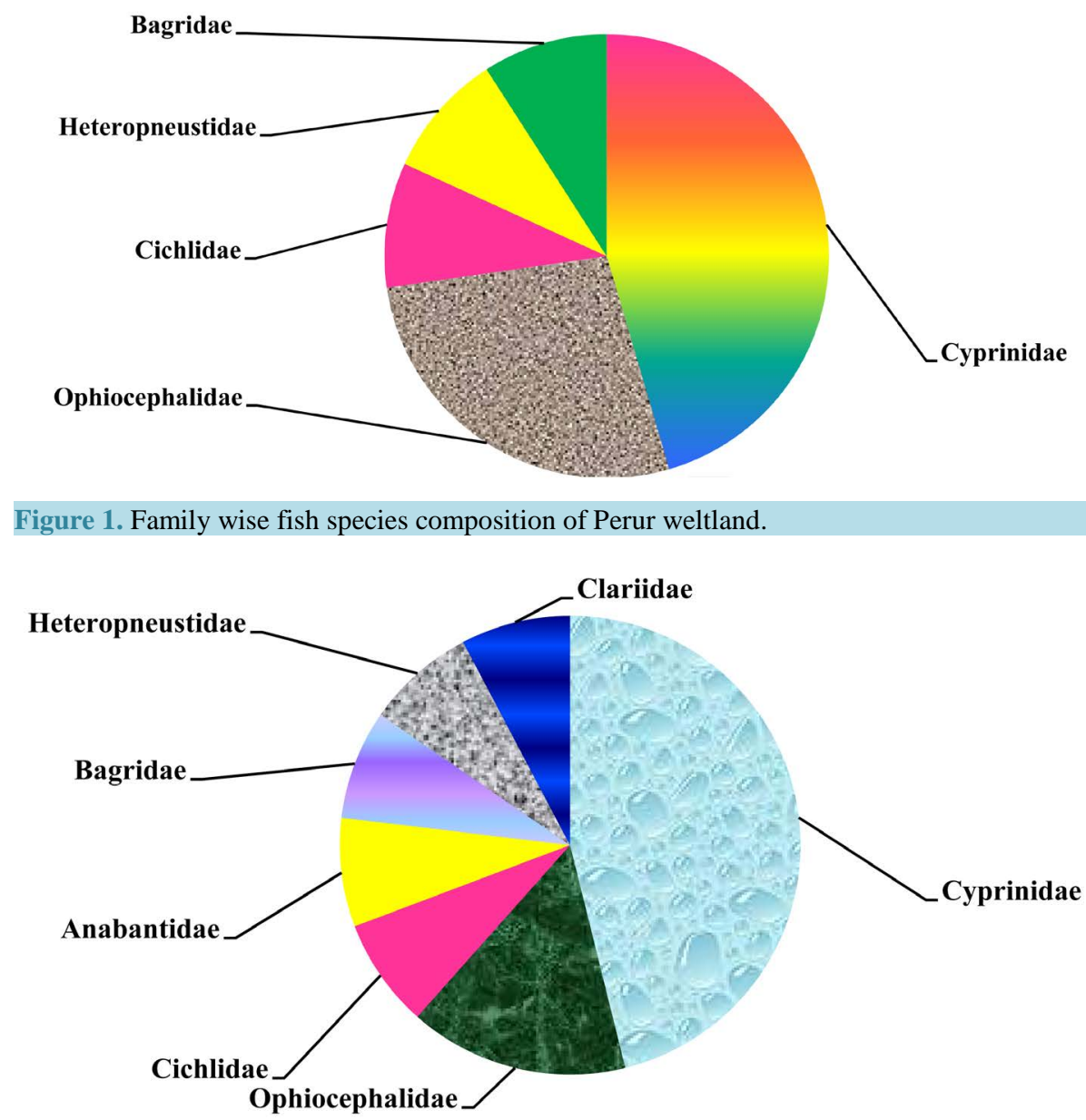

Figure 2. Family wise fish species composition of Muthanakulam weltland. 


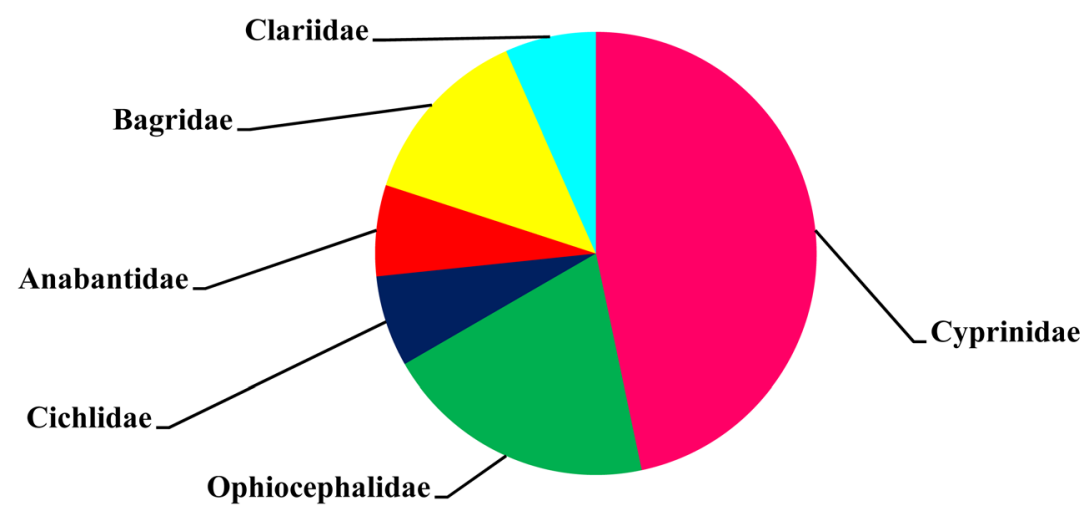

Figure 3. Family wise fish species composition of Kurichi weltland.

punctatus belonging to Ophiocephaliformes. The other 2 fish species belonging to the same family was less abundant followed by Anabas testudineus. Battul et al., [16]; Sharma [17]; Ubharane et al. [18] also stated that Cyprinidae family was maximum during their study period in their study area.

\section{Conclusion}

From the present piscine investigation data, it was concluded that all most all the selected wetlands for the present study even though considered to be healthy water bodies providing a good habitat for fresh water fishes of diverse type are still considered to be under constant threat to fish population due to eutrophication and illegal fishing activities. It is suggested that the illegal fishing activities should be banned to prevent depletion of fresh water fish resources further fishery authorities should practice the proper management of this inland fishery resources. Further studies should be conducted to generate more details regarding seasonal production and ecology of fishes to provide future strategies for the development and conservation of fish fauna. Thus it is necessity of every individual to play an active role to achieve the goals of sustainable fishery development and handover the resources in healthy conditions to the future generations.

\section{Acknowledgements}

We are grateful to Fishery Officer, Coimbatore for his valuable suggestions and inspiration. The authors are thankful to the PG and Research Department of Zoology, Nirmala College for Women for providing laboratory assistance, kind help and necessary support during the sample and field work.

\section{References}

[1] Ehrlich, P.R. and Wilson, E.O. (1991) Biodiversity Studies Science and Policy. Science, 253, 758-762. http://dx.doi.org/10.1126/science.253.5021.758

[2] Jayaram, K.C. (2010) The Freshwater Fishes of the Indian Region. 2nd Edition, Narendra Publishing House, Delhi, $616 \mathrm{p}$.

[3] Qureshi, T.A. and Qureshi, N.A. (1983) Indian Fishes Publishers Brij Brothers, Sultania Road Bhopal (M.P.). 5-209.

[4] Talwar, P.K. and Jhingran, A.G. (1991) Inland Fishes of India and Adjacent Countries. Oxford-IBH Publishing Co. Pvt. Ltd., New Delhi, 1158 p.

[5] Francis, D. (1994) The Fishes of India, Jagmander. Book Agency, New Delhi.

[6] Shrivastava, G. (1998) Fishes of U.P. and Bihar. 7th Edition, Vishwavidalay Prakashan, Chowk Varanasi India Pub.

[7] Kharat, S.S., Paingankar, M. and Dahanukar, N. (2012) Freshwater Fish Fauna of Krishna River at Wai, Northern Western Ghats, India. Journal of Threatened Taxa, 4, 2644-2652. http://dx.doi.org/10.11609/JoTT.o2796.2644-52

[8] Muhammad, G.S., Abu, N.S.M., Mohsin, A.B.M., Nipa, C. and Md Foyzul Hassan, F. (2013) Fish Diversity of the River Choto Jamuna, Bangladesh: Present Status and Conservation Needs. International Journal of Biodiversity and Conservation, 5, 389-395.

[9] Nagabhushana, C.M. and Hosetti, B.B. (2013) Limnological Profile for the Sustained Fish Production in Tungabhadra Reservoir, Hospet. Global Journal for Research Analysis, 2, 1-2. 
[10] Chandrashekar, B.S. (2014) Fishery Co-Operative Societies in India: Problems and Prospects. Global Journal for Research Analysis, 3, 92-94.

[11] Biswas, B.C. and Panigrahi, A.K. (2014) Abundance of Pisces and Status of Water of Mathabhanga-Churni River in Indo-Bangla Border Region. Global Journal for Research Analysis, 3, 281-283. http://dx.doi.org/10.15373/22778160/July2014/102

[12] Sakhare, V.B. (2001) Ichthyofauna of Jawalgaon Reservoir in Solapur District (M.S.). Journal of Aquatic Biology, 16, 31-33.

[13] Choubey, K. and Qureshi, Y. (2013) Study of Ichthyofaunal Biodiversity of Rajnandgaon Town, CG, India. International Research Journal of Biological Sciences, 2, 21-24.

[14] Narasimha Ramulu, K. and Benarjee, G. (2013) Physico-Chemical Factors Influenced Plankton Biodiversity and Fish Abundance-A Case Study of Nagaram Tank of Warangal, Andhra Pradesh. International Journal of Life Sciences Biotechnology and Pharma Research, 2, 248-260.

[15] Nagma and Khan, M.A. (2013) Studies on Freshwater Fish Fauna of District Bijnor in Western Uttar Pradesh, India. International Journal of Life Sciences Biotechnology and Pharma Research, 2, 410-417.

[16] Battul, P.N., Rao, R.A., Navale, K.R., Bagale, M.B. and Shah, N.V. (2007) Fish Diversity from Ekrukh Lake Near Solapur Maharashtra. Journal of Aquatic Biology, 22, 68-72.

[17] Sharma, C.M. (2008) Freshwater Fishes, Fisheries and Habitat Prospects of Nepal. Aquatic Ecosystem, Health and Management, 11, 75-82. http://dx.doi.org/10.1080/14634980802317329

[18] Ubarhande, S.B., Jagtap, J.T. and Sonawane, S.R. (2011) Ichthyofanal Diversity from Ambadi Dam, Taluka Kannad, District Aurangabad (Maharashtra). Recent Research in Science and Technology, 3, 34-37. 